\title{
Predicting suitable habitat for deep-water gorgonian corals on the Atlantic and Pacific Continental Margins of North America
}

\author{
Tanya L. Bryan*, Anna Metaxas \\ Department of Oceanography, Dalhousie University, Halifax, Nova Scotia B3H 4J1, Canada
}

\begin{abstract}
Mapping marine habitats and species distributions is essential in conservation and resource management. The generation of such maps, however, is particularly challenging for the poorly sampled deep-sea species. In this study, we explored the spatial suitability of deep-water coral (Families Paragorgiidae and Primnoidae) habitat on both the Pacific and Atlantic Continental Margins of North America (PCM and ACM) using Biomapper, a modeling program which can determine habitat suitability using presence-only data. The PCM study area was divided into 2 regions to limit the geographic size of the modelled area: PCM:AK, which encompasses Alaska and PCM:BC-CA, which encompasses British Columbia, Washington, Oregon, and California. Suitable habitat was determined based on quantitative relationships between physical seascape factors and biological data. For the PCM study area, the most accurate model for Paragorgiidae in PCM:AK combined temperature, slope, current and chlorophyll (chl) a concentration (Spearman's $\rho=0.79$ ), whereas in the PCM:BC-CA it combined depth and chl a concentration $(\rho=0.66)$. For Primnoidae, in the PCM:AK the most accurate combination included depth, slope, current and chl a concentration $(\rho=0.90)$, and in the PCM:BC-CA, it included depth, temperature, slope and current $(\rho=0.85)$. In the ACM study area, the most accurate model for Paragorgiidae combined temperature, slope and chl a concentration $(\rho=0.71)$, whereas the one for Primnoidae combined temperature, slope, current and chl a concentration $(\rho=0.74)$. In both study areas, corals were predicted to occur in areas of complex topography, mainly along the continental shelf break and on seamounts. Sensitivity analyses indicated that predicted mean values of seascape factors, in coral habitat as well as niche breadth, varied with number of coral locations, but to a much lesser extent with spatial resolution. To our knowledge, this is the first study to use Biomapper for the prediction of suitable habitat in marine species.
\end{abstract}

KEY WORDS: Deep-water gorgonian corals - Paragorgiidae · Primnoidae · Habitat modeling • Biomapper · Continental margin · Environmental factors · Suitable habitat

\section{INTRODUCTION}

Mapping marine habitats and associated species distributions is fundamental in determining locations of potential protected areas, assisting in resource management and assessing anthropogenic impacts. Although advancements in surveying technologies have increased the accuracy of large-scale mapping projects in shallow-water marine systems, data collection from deep-water environments is considerably more diffi- cult. Consequently, data on the spatial distribution of most deep-water benthic species are also sparse.

Deep-water corals have been receiving attention because of the increased diversity and abundance of associated organisms relative to the surrounding deep sea, and because of their vulnerability to human impact. They are primarily found in areas of pronounced topographic relief, at depths ranging from 10 to $3500 \mathrm{~m}$ (Cimberg et al. 1981, Mortensen et al. 2001). Corals are abundant on slopes, in and around subma- 
rine canyons, gullies and on the edge of the continental shelf (MacIsaac et al. 2001). These sloping areas are normally associated with hard substrate, such as cobble and boulders, making them suitable for coral attachment (Freiwald et al. 1999). Because of the rarity of hard substrate in the deep sea, areas of high vertical relief often harbour abundant communities of benthic organisms, including deep-water corals (Herring 2002). Typically, these areas are also associated with strong current regimes (Genin et al. 1986, Herring 2002). As they are sessile filter feeders, deep-water corals rely on currents to provide nutrition as well as to remove sediments which may smother them. Consequently, corals are usually associated with strong current velocities or unique current patterns such as recirculation gyres, which in turn are indicative of increased concentrations of particles (Moore \& Bullis 1960, Tendal 1992). Historically, the distribution of deep-water corals has been determined only through fishers' records, and thus mapping of habitats where these organisms are abundant is spatially unreliable.

Habitat suitability (HS) maps can provide the first estimate of potential distribution of deep-water species, including corals. Such maps can be generated by habitat modelling, a method which examines relationships between the presence and/or absence of species and relevant environmental parameters. There are many different techniques used to generate habitat maps, but these techniques are frequently limited by the type of available data. Because of the remoteness and low accessibility of deep-water marine environments, often only information on species presence is available, constraining the range of suitable habitat models.

One statistical technique that can be used to generate habitat maps is ecological niche factor analysis (ENFA), using the modelling program Biomapper (Hirzel 2001). ENFA generates HS maps by relating species presence data with background environmental variables to determine the species' niche (Hirzel et al. 2002). This program also incorporates descriptive statistics, as well as a Geographic Information System (GIS), for generating HS maps. ENFA has been utilized to generate HS maps for terrestrial floral and fauna, such as ferns in New Zealand as well as ibex, bearded vultures and alpine mice in Switzerland (Hirzel 2001, Zaniewski et al. 2002, Reutter et al. 2003, Hirzel \& Arlettaz 2003). This modelling approach is extremely useful when absence data are not available (e.g. most deep-water datasets), are unreliable (e.g. cryptic or rare species), or are ecologically meaningless (e.g. invading species) (Reutter et al. 2003). Several studies have compared the results of ENFA with more traditional statistical analyses, such as generalized linear models (GLM), by randomly generating pseudoabsences, and indicated that ENFA outperformed
GLM when the species were rare or cryptic (Hirzel et al. 2001, Guisan \& Zimmerman 2002, Hirzel \& Arlettaz 2003).

This study used ENFA to generate HS maps for deep-water coral on the Pacific Continental Margin (PCM) and in the Atlantic Continental Margin (ACM) of North America. We used 2 families, Paragorgiidae and Primnoidae, to maximize the number of known presence locations. We also compared the relative importance of 5 environmental factors (depth, temperature, slope, current and chlorophyll [chl] a concentration) in determining suitable habitat for each taxonomic group. These factors were selected based on available data in locations where coral have been recorded (MacIsaac et al. 2001, De Mol et al. 2002, Freiwald 2002). This is the first study to use ENFA in the marine environment. By using this technique, we were able to include previously unusable or underused data collections and attempt to locate previously unknown areas of potentially high coral abundance, based on suitability of the habitat.

\section{MATERIALS AND METHODS}

Study area. Study sites were selected along the PCM and ACM. The PCM study area encompassed a section approximately $1000 \mathrm{~km}$ wide and $3500 \mathrm{~km}$ long, from Alaska to California (Fig. 1). This site was defined by a wide continental shelf $(\sim 100 \mathrm{~km}$ wide $)$ and a narrow $(\sim 70 \mathrm{~km}$ wide) but steep continuous slope (from shelf break to $\sim 5000 \mathrm{~m}$ deep; Leier 2001). This sharp gradient is the result of active subduction zones close to the continent. Near the continent, this study area also contains many islands that channel water resulting in high current speeds. For ENFA analyses, the PCM study area was divided into 2 regions to limit the geographic size of the modelled area: PCM:AK, which encompasses Alaska ( 900 km wide and $\sim 1900 \mathrm{~km}$ long) and PCM:BC-CA, which encompasses British Columbia, Oregon, Washington and California $(1000 \mathrm{~km}$ wide and $\sim 1400 \mathrm{~km}$ long).

The ACM study area included a band $\sim 300 \mathrm{~km}$ wide and $800 \mathrm{~km}$ long from Cape Breton to Cape Cod (to $\sim 500 \mathrm{~m}$ in average depth; Fig. 2). This area was defined by a $200 \mathrm{~km}$ wide continental shelf and a $250 \mathrm{~km}$ wide continental slope (sloping to $4000 \mathrm{~m}$ in depth) (Elsner 1999, Gordon \& Fenton 2002). The continental shelf is composed of large, shallow banks surrounded by several basins and troughs along the inner shelf, as well as many canyons along the outer shelf. This topography influences through-flow and local recirculation of water masses (Hannah et al. 2001). Choice of both study areas was based on the observed high density of known coral sites. 


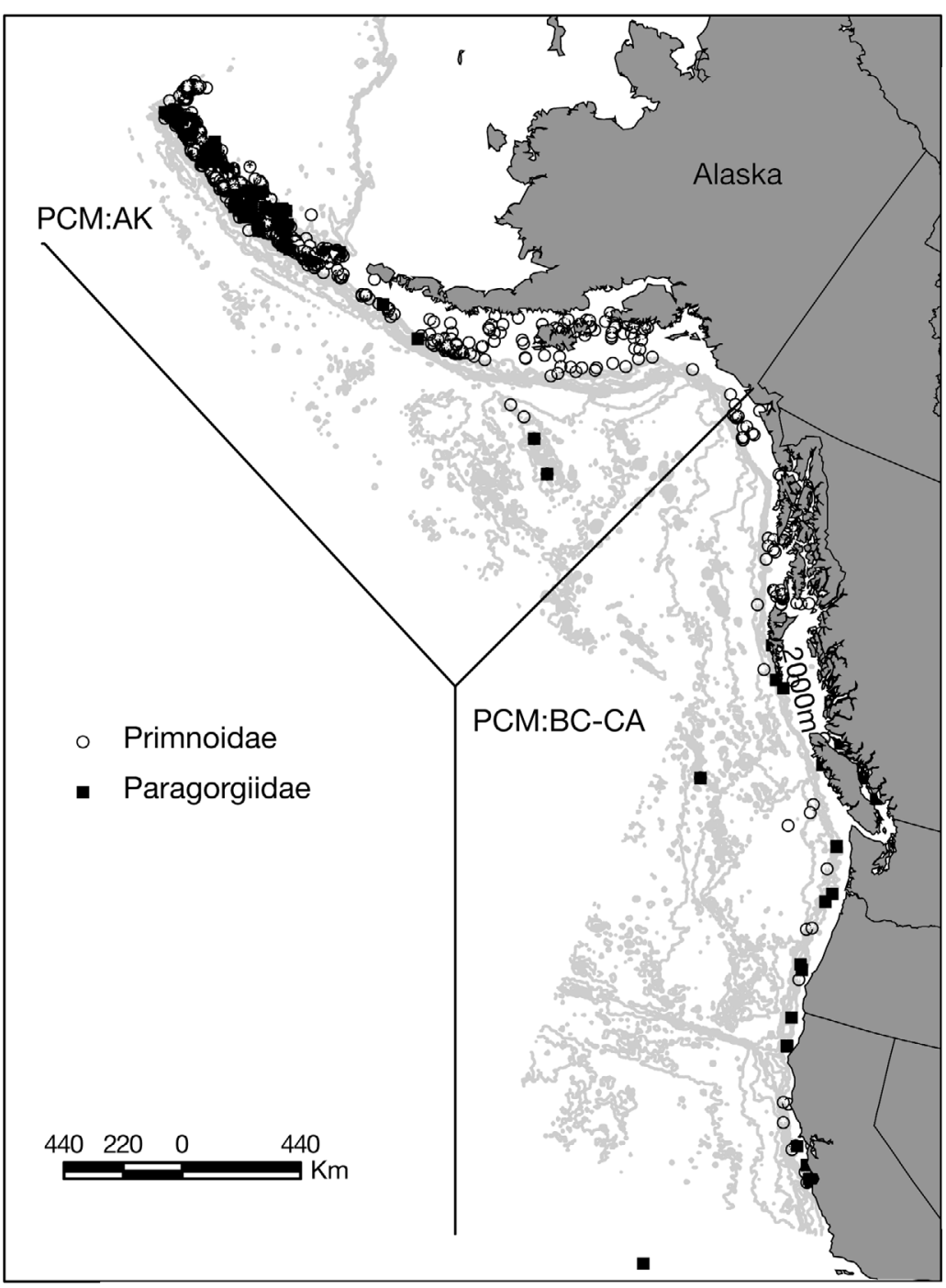

Fig. 1. Known locations of Paragorgiidae and Primnoidae along the Pacific Continental Margin (PCM) study area. AK: Alaska, BC-CA: British Columbia-California. Contours: $500 \mathrm{~m}$ (starting contour $500 \mathrm{~m}$ ); $2000 \mathrm{~m}$ contour shown for reference

Data collection. Sources of environmental data on depth, slope, temperature, current speed and chl a concentration for both study areas are given in Table 1. Sources are mostly of empirical data, except for current velocity, which was obtained through oceanographic circulation models.

For the PCM study area, data on coral locations were obtained from the Marine Conservation Biology Institute (MCBI, Bellevue, WA; Etnoyer 2003). Data for this dataset were provided to MCBI by many institutions, including the California Academy of Sciences, the Smithsonian Institution National Museum of Natural History, NOAA Fisheries RACEBASE, the Canadian Museum of Nature, the Monterey Bay Aquarium Research Institute, Scripps Institution of Oceanogra- phy, the Santa Barbara Museum of Natural History, as well as by Cimberg et al. (1981). This database is based on coral identification by 4 levels of expertise, ranging from scientific expertise to recreation diver. However, we included all observations to maximize sample size of coral locations.

Coral observations in the ACM study area were obtained from Breeze et al. (1997), Gass (2002) and Watling (2005). The data summarized in these reports were acquired mainly through interviews with fishers and historical records.

In both study areas, coral observations were grouped to family to allow the inclusion of all location data. In the PCM study area, Paragorgiidae included 2 species (Paragorgiia arborea and $P$. pacifica), while Primnoidae included 11 species in 9 genera (Amphilaphis sp., Arthrogorgia sp., Callogorgia kinoshitae, Fanellia compressa, F. fraseri, Narella bowersi, Parastenella doederleini, Plumarella longispina, Primnoa resedaeformis, Primnoa willeyi, Thouarella sp.; Etnoyer 2003). In the ACM study area, Paragorgiidae consisted of Paragorgia arborea, and Primnoidae of Primnoa resedaeformis (Gass 2002).

Minimum, maximum, and average values were calculated for temperature and chl $a$ in the ACM study area, but were not available for the PCM study area. Salinity was not included as an environmental variable in the analysis because the variation within the study area was small $190 \%$ of the coral locations falling between 34.5 and $35.5 ; \mathrm{T}$. L. Bryan unpubl. data). We used depth ranges of 0 to $2000 \mathrm{~m}$ for PCM and 0 to $500 \mathrm{~m}$ for ACM to ensure adequate representation of depth in coral observations. The frequency of coral observations in these ranges closely reflects the frequency of depth strata in the study area (Fig. 3). There were $\leq 17 \%$ coral recorded at locations outside these depth ranges. In both study areas, coral location records were primarily obtained from fishers and scientific research cruises. In the PCM study area, these efforts are mainly restricted to $>2000 \mathrm{~m}$ and are mostly focused on the continental shelf and on seamounts. In the ACM study area, most fishing and scientific studies have been focussed at depths between 200 and $500 \mathrm{~m}$. In both study areas, 


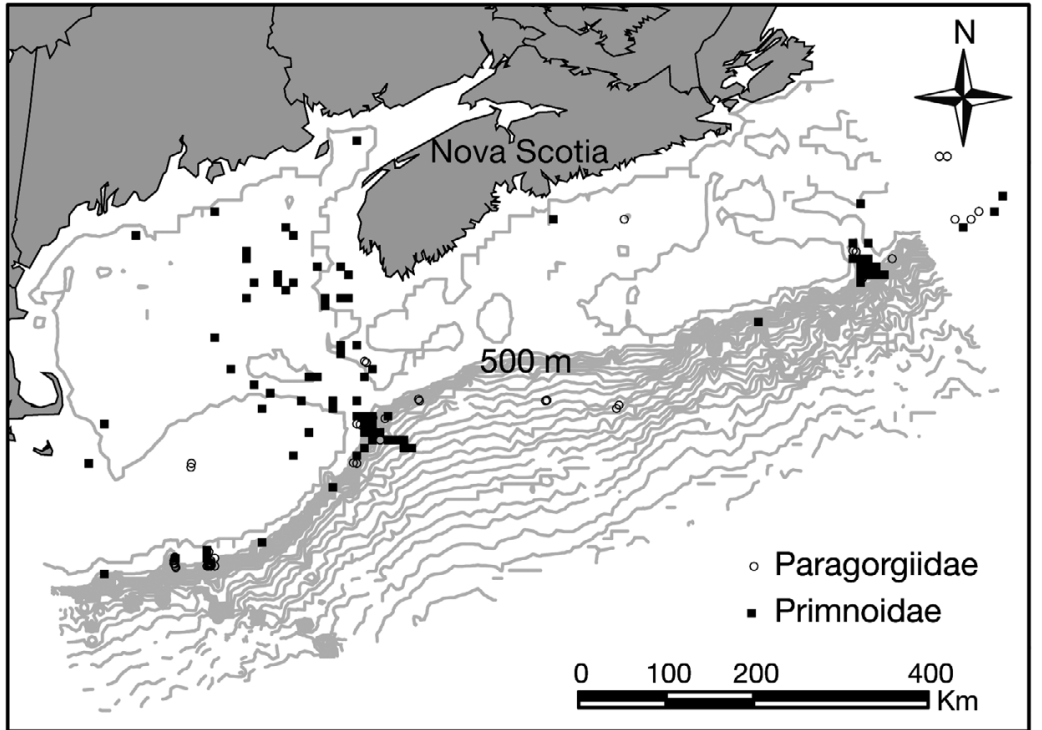

Fig. 2. Known locations of Paragorgiidae and Primnoidae along the Atlantic Continental Margin (ACM) study area, from Cape Breton to Cape Cod. Contours: $200 \mathrm{~m}$ (starting contour $100 \mathrm{~m}$ ); $500 \mathrm{~m}$ contour shown for reference by geological surveys (e.g. USGS) can only be interpolated accurately on scales of $9 \times 9 \mathrm{~km}^{2}$, and they are of limited spatial coverage (Institute of Arctic and Alpine Research, Boulder, CO, unpubl. data). Typically, gorgonian corals occur on isolated cobbles, boulders and rocky outcrops scattered within areas covered by sand or mud (e.g. Mortensen \& Buhl-Mortensen 2004), which would not be identified on these coarser resolutions. Bottom topography (quantified as slope in our study) can be used as a proxy for locations with hard substrate, since areas of pronounced topographic relief will exhibit low sedimentation rates (Genin et al. 1986, Freiwald et al. 1999, Herring 2002).

Ecological niche factor analysis. ENFA is similar to principal component analysis (PCA) in that it determines relationships between variables and finds combinations of these variables to

depths > $1000 \mathrm{~m}$ are under-sampled compared with shallower locations.

Despite its potential importance, we did not include substrate in this study as an environmental parameter used to predict suitable habitat. Current geological maps are of little use for our models since substrate has been characterized patchily based on point estimates of average grain size. Presently, unpublished data sets collected produce uncorrelated indices or components (Manly 1986). These components represent composite factors that explain variability. In ENFA, however, unlike PCA, the components have direct ecological meaning. The first component is defined as the 'marginality' of the species' niche, which describes the mean of the species distribution in relation to the mean of the global (study) distribution. It is defined as 'the absolute

Table 1. Sources and types of environmental data used in this study. PCM and ACM: Pacific and Atlantic Continental Margins (of North America), respectively

\begin{tabular}{|c|c|c|c|}
\hline Study area & Environmental variable & Source & Type of data \\
\hline \multirow[t]{4}{*}{$\mathrm{PCM}$} & Depth/slope & $\begin{array}{l}\text { Marine Conservation } \\
\text { Biology Institute, USA }\end{array}$ & $\begin{array}{l}\text { Derived from bathymetry data composed } \\
\text { of a } 2 \text { min resolution grid }\end{array}$ \\
\hline & Bottom temperature & $\begin{array}{l}\text { Don Spears, Marine } \\
\text { Environmental Data Services } \\
\text { Branch (MEDS), Canada }\end{array}$ & $\begin{array}{l}\text { Each point was averaged from seafloor to } \\
\text { include all data points in the water column to } \\
\text { a maximum depth of } 50 \mathrm{~m} \text { above the seafloor }\end{array}$ \\
\hline & Bottom current velocity & $\begin{array}{l}\text { Mike Foreman, Institute of } \\
\text { Ocean Science, Canada }\end{array}$ & $\begin{array}{l}\text { Modelled data, tidal velocities modelled for } \\
\text { winter, spring, summer, fall and then } \\
\text { averaged for the year }\end{array}$ \\
\hline & $\begin{array}{l}\text { Surface chl a } \\
\text { concentration }\end{array}$ & $\begin{array}{l}\text { Marine Conservation Biology } \\
\text { Institute, USA }\end{array}$ & $\begin{array}{l}\text { Derived MODIS images, yearly average } \\
\text { includes 1997-1999 }\end{array}$ \\
\hline \multirow[t]{4}{*}{$\mathrm{ACM}$} & Depth/slope & $\begin{array}{l}\text { World Wildlife Fund Canada } \\
\text { (Alidina \& Roff 2003) }\end{array}$ & $\begin{array}{l}\text { Derived from bathymetry data composed of a } \\
5 \text { min resolution grid }\end{array}$ \\
\hline & Bottom temperature & $\begin{array}{l}\text { World Wildlife Fund Canada } \\
\text { (Alidina \& Roff 2003) }\end{array}$ & $\begin{array}{l}\text { Each point was averaged from seafloor to } \\
\text { include all data points in the water column to } \\
\text { a maximum depth of } 50 \mathrm{~m} \text { above the seafloor }\end{array}$ \\
\hline & Bottom current velocity & $\begin{array}{l}\text { Charles Hannah, Bedford } \\
\text { Institute of Oceanography, } \\
\text { Canada (Hannah et al. 2001) }\end{array}$ & Modelled data, annual tidal velocities \\
\hline & $\begin{array}{l}\text { Surface chl a } \\
\text { concentration }\end{array}$ & $\begin{array}{l}\text { Moderate Resolution Imagining } \\
\text { Spectroradiometers (MODIS) }\end{array}$ & $\begin{array}{l}\text { Derived MODIS images, averaged from } \\
1998-2001\end{array}$ \\
\hline
\end{tabular}




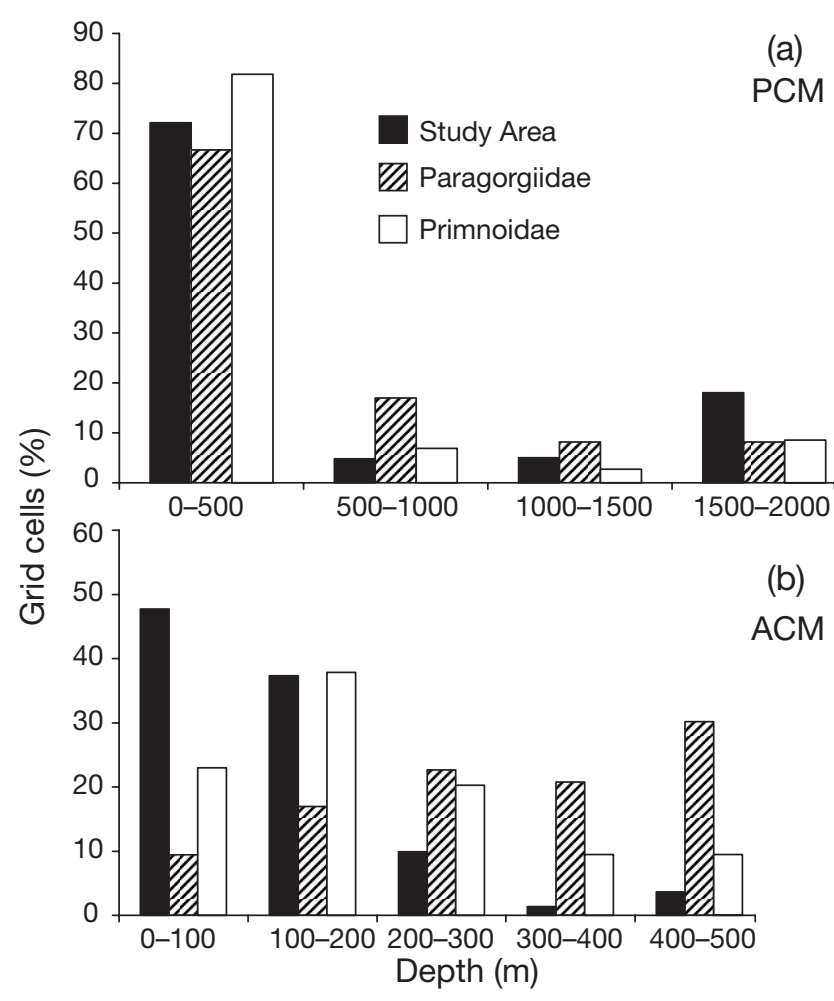

Fig. 3. Distribution of depths (grid cell size: $5 \times 5 \mathrm{~km}^{2}$ ) across the entire study area, as well as in locations of Paragorgiidae and Primnoidae in the (a) PCM and (b) ACM study areas

difference between the global mean and the species mean' for each environmental variable (Hirzel et al. 2002) and is calculated as:

$$
m_{i}=\frac{\left|m_{G_{i}}-m_{S_{i}}\right|}{1.96 \sigma_{G_{i}}}
$$

where $m_{i}$ is the marginality for a particular environmental variable, $m_{G_{i}}$ is the global mean of the variable, $m_{s_{i}}$ is the mean of the variable in species' range and $\sigma_{G_{i}}$ is the standard deviation of the global distribution for the variable. The first component in ENFA is chosen to account for $100 \%$ of the marginality of the species, as well as some proportion of specialization, with the remaining components maximizing the remaining amount of specialization of the species (Hirzel 2001).

The remaining components explain progressively decreasing amounts of the 'niche specialization' of the species. Specialization indicates how restricted the species' niche is in relation to the study area and is defined as 'the ratio of variance in the global distribution to that in the species distribution' of the environmental variable (Hirzel et al. 2002, Reutter et al. 2003). It is calculated as:

$$
\lambda_{i}=\frac{\sigma_{G_{i}}}{\sigma_{S_{i}}}
$$

where $\lambda_{i}$ is the specialization for a particular environmental variable and $\sigma_{S_{i}}$ is the standard deviation of the variable in the species' range. Eigenvalues associated with specialization components can be larger than the values associated with the marginality values (Hirzel 2001). The coefficients of each environmental factor indicate the magnitude of variance in HS that they explain. Along the marginality component, the signs of the coefficients indicate whether the suitable habitat is represented by above-average (positive coefficients) or below-average (negative coefficients) values of the environmental variable. The signs of the coefficients are meaningless along the specialization components as the analysis uses absolute values.

Combining the marginality of individual environmental variables, ENFA then computes an overall global marginality (Hirzel et al. 2002, Reutter et al. 2003) as:

$$
M=\frac{\sqrt{\sum_{i=1}^{V} m_{i}^{2}}}{1.96}
$$

where $V$ is the number of environmental variables. $M$ generally ranges between 0 and 1 , with large values indicating that the species is not equally represented in all environments. Extreme conditions may force this value higher than 1. It also calculates a global specialization coefficient as:

$$
S=\frac{\sqrt{\sum_{i=1}^{V} \lambda_{i}}}{1.96}
$$

$S$ ranges from 1 to $\infty$, with the niche becoming narrower as $S$ increases. Tolerance, which is the inverse of specialization, ranges from 0 to 1 , with a larger coefficient indicating a wider niche for a particular species (Reutter et al. 2003).

Coral location data for each Paragorgiidae and Primnoidae record, as well as environmental data (temperature, slope, current and chl a) for both study areas, were imported into Biomapper as a raster-based grid file with a $5 \times 5 \mathrm{~km}^{2}$ cell size. This resolution was selected based on the resolution of the original environmental data. In the PCM study area, slope was originally plotted at $2 \mathrm{~min}$ resolution, temperature at approximately a $5 \mathrm{~min}$ resolution, current using a $15 \mathrm{~km}$ uniform grid and chl a concentration using $9 \mathrm{~km}$ grid. In the ACM study area, temperature and slope were plotted at 5 min resolution, current using a $15 \mathrm{~km}$ uniform grid and chl a concentration at $1.5 \times 1.5 \mathrm{~km}$ resolution. Although some of the original data were plotted in degrees, utilising a resolution based on kilometres enabled us to incorporate the variation in latitude width within the study area. By interpolating using a $5 \times 5 \mathrm{~km}^{2}$ grid, as well as a higher power to place greater emphasis on nearby points, we were able to maintain the accuracy of the original data. 
Environmental variable maps were transformed using the Box-Cox transformation, which optimises the normality of the distributions (Sokal \& Rohlf 1995). Using the median algorithm, ENFA was used to obtain marginality and specialization values, which indicated those environmental parameters with the greatest influence (weight) on the distribution of each coral family. This algorithm assumes that the median value for the environmental variable in the species distribution is approximately the same as in the study area and makes no assumptions based on the density of observation points (Hirzel et al. 2002, Hirzel \& Arlettaz 2003). These assumptions were verified for this dataset.

Map generation. HS maps were constructed from the ENFA results as follows. Firstly, the value of each environmental factor at each location of coral occurrence was determined. A frequency histogram was generated with these values, and scores were assigned to each class in the histogram. Assuming a normal distribution, these scores are maximal at the median of the distribution and decrease towards either tail (Hirzel et al. 2002). Secondly, the class of each cell in the study area was determined for that environmental factor and a suitability value ('partial suitability') assigned, based on the score of that class in the histogram. The further the class of the cell was from the median, the lower was the HS of the cell. A global suitability value for all environmental factors was then generated for each cell by computing the weighted mean of all partial suitabilities. The global suitability values were rescaled using the isopleth method to range from 0 to 100 , with zero being completely unsuitable (Hirzel 2001). The isopleth method generates classes of suitability values based on their distribution. It assigns class boundaries to allow an equal number of cells in each class (e.g. $25 \%$ of the cells in the study area are found in classes of 75 or greater and $50 \%$ found in classes of 50 or greater). A HS map is plotted using the scaled global suitability values for each cell and the HS index is calculated from the study area. This classification of scaled global suitability values becomes the HS index. This method does not assume that all observations are located in optimal habitat. As corals are sessile, all observations should theoretically be within highly suitable areas. But, because of the coarse resolution of the environmental maps, this assumption may not always be valid. Predicted locations were indicated only as being either suitable or unsuitable and not assigned to within a range of suitability because of the low spatial resolution of the analysis.

Validation of HS maps. Validation and confidence limits for the HS map were calculated using a built-in jackknifing method in which coral location data were partitioned into 10 equal-sized subsets. Nine of these subsets were used to generate the HS map and the remaining subset was used for validation (Fielding \& Bell 1997, Boyce et al. 2002). This procedure was repeated 10 times, with a new subset being used for validation each time. For each validation subset, the observations were categorized into 4 equal sized bins of HS index $(0-0.25,0.26-0.50,0.51-0.75,0.76-1.00)$. For each validation subset, the area-adjusted frequency $\left(F_{\text {aa }}\right)$ was calculated for each HS bin. $F_{\text {aa }}$ is defined as the proportion of validation points in the HS bin, divided by the proportion of the study area covered by the bin, and was calculated as:

$$
F_{\text {aa }}=\frac{\frac{N_{(j)}}{N}}{\frac{S_{(j)}}{S}}
$$

where $N_{(j)}$ is the number of validation points in the $j$ th bin, $N$ is the total number of validation points, $S_{(j)}$ is the map's total area covered by the $j$ th bin, and $S$ is the total area of the map. The range of $F_{\text {aa }}$ depended on the number of observations, as well as the size of the study area. In an HS map generated based on a randomly distributed species, increasing HS values should be associated with increasing $F_{\text {aa }}$ values. The habitat is defined as unsuitable when $F_{\text {aa }}$ is $<1$. Thus, the $F_{\text {aa }}$ values were used to distinguish the boundary between suitable and unsuitable habitat for each coral family. For each validation subset, $F_{\text {aa }}$ values were correlated with the binned HS index using a Spearman's rank correlation. These rankings were averaged among validation subsets to produce a mean Spearman's rho $(\rho)$, which indicates the relative accuracy of the particular combination of environmental variables at predicting coral locations. Spearman's rank correlation is not sensitive to discriminate between $\rho$ values very near or equal to 1 .

Sensitivity analyses. To test the sensitivity of map generation to changes in input parameters, 3 approaches were used. Firstly, coral locations were randomly removed to determine whether the number of observations significantly affected $\rho$ values. Using the Primnoidae dataset $(\mathrm{N}=612)$ from the entire PCM study area (to maximize sample size), the number of coral locations was reduced by 10, 30, 50 and $90 \%$, respectively. Ten randomly generated sets of locations were calculated for each percentage reduction. These sets were analysed in Biomapper using 4 environmental factors (temperature, slope, current and chl a concentration) to obtain a maximum and minimum value for marginality, tolerance and $\rho$ values.

In the second approach, we used the Primnoidae data from the ACM study area because minimum, maximum and average values for temperature and 
chl a were available. We used 9 possible environment combinations containing all 4 environmental variables to calculate HS maps. Each combination included the same values of slope and current. The remaining 2 environmental variables in each combination were all possible permutations of temperature (minimum, maximum, average) and chl a concentration (minimum, maximum, average).

In the third approach, using the Primnoidae data from the entire PCM study area, we interpolated each environmental variable to a higher resolution of $1 \mathrm{~km}^{2}$ $(1 \times 1)$ and a lower resolution of $81 \mathrm{~km}^{2}(9 \times 9)$. We then compared marginality, tolerance and $\rho$ values for models including each of the 11 possible combinations of the 4 environmental variables among resolutions.

\section{RESULTS}

\section{ENFA and HS map generation}

The combination of factors that most accurately predicted suitable habitat for coral was determined by running ENFA for each of all possible combinations of environmental variables. To compare the accuracy of combinations between runs, we used Spearman's $\rho$ values.

In the PCM study area for Paragorgiidae, $\rho$ values ranged from 0.02 to 0.79 in the PCM:AK region (Fig. 4a), and 0.12 to 0.66 in the PCM:BC-CA region (Fig. $4 \mathrm{~b}$ ). In the PCM:AK region, the highest $\rho$ value was 0.79 for the model that combined temperature, slope, current and
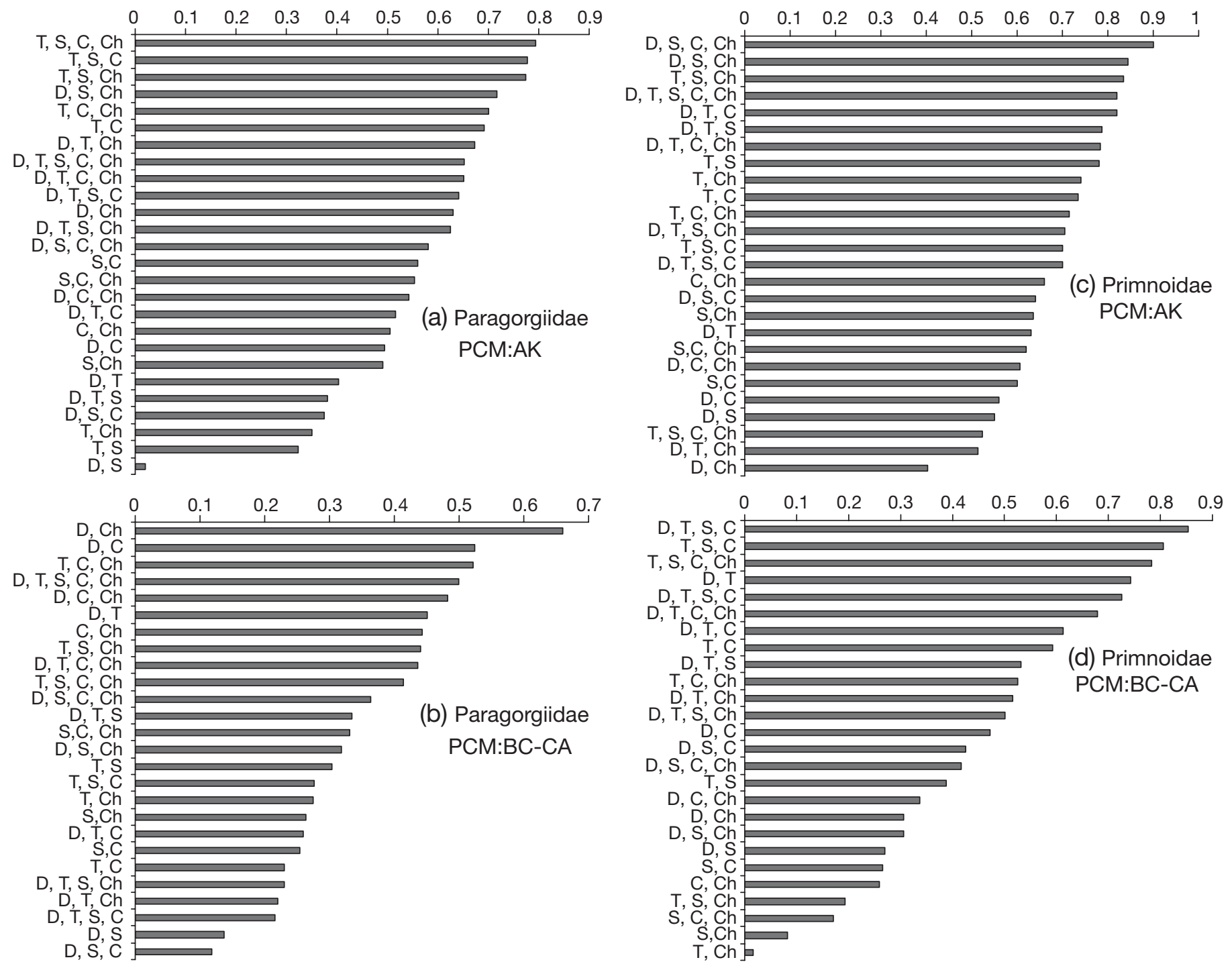

Fig. 4. Spearman's $\rho$ for (a) Paragorgiidae - PCM:AK, (b) Paragorgiidae - PCM:BC-CA, (c) Primnoidae - PCM:AK and (d) Primnoidae - PCM:BC-CA, using all possible combinations of environmental variables to determine suitable habitat for the PCM study area. D: depth, S: slope, T: temperature, C: current, Ch: chl a concentration. See Fig. 1 for delineation of regions 

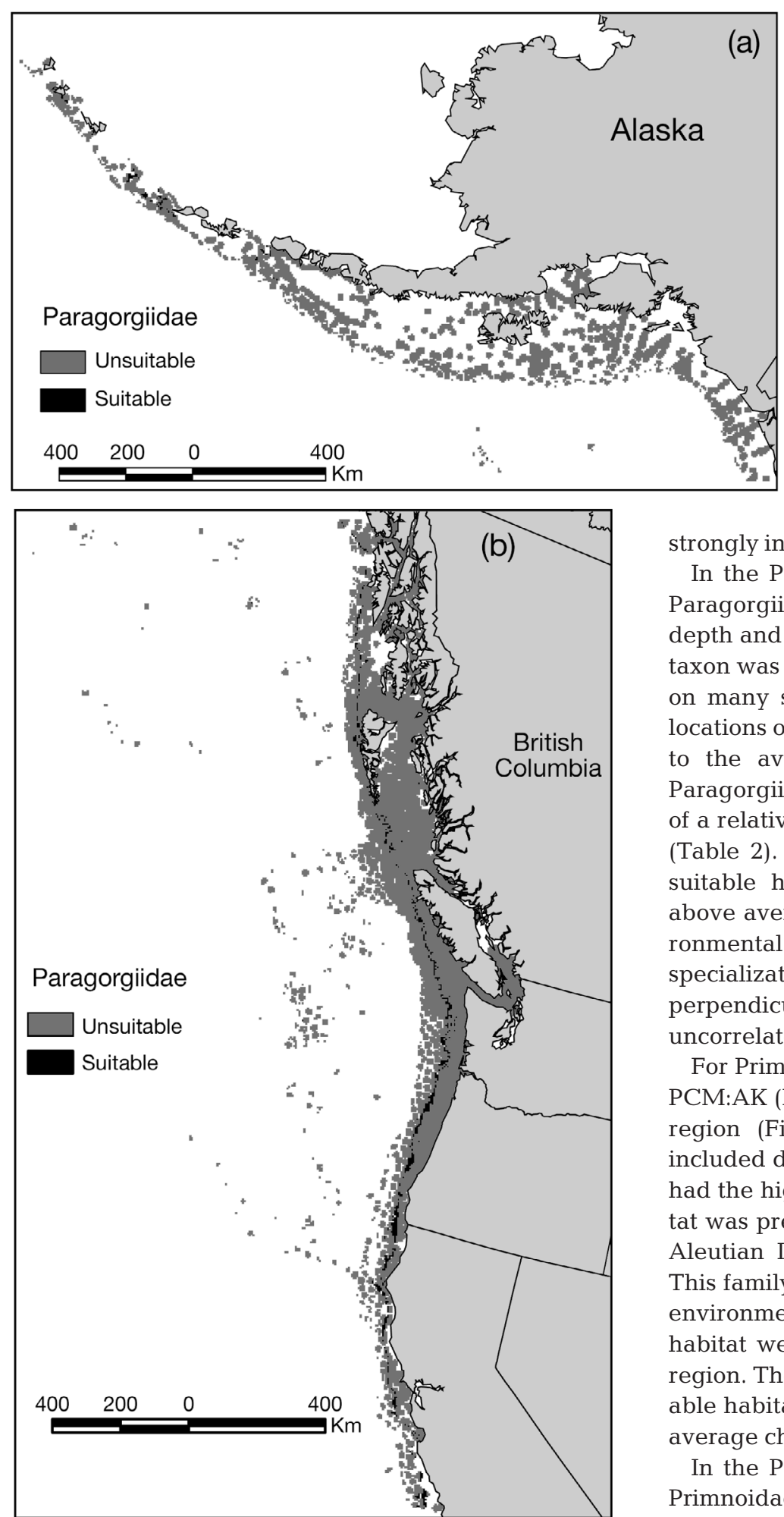

Fig. 5. Habitat suitability map for Paragorgiidae in the PCM study area generated by ecological niche factor analysis. (a) PCM:AK region, using the combination of temperature $\left({ }^{\circ} \mathrm{C}\right)$, slope $\left({ }^{\circ}\right)$, current $\left(\mathrm{cm} \mathrm{s}^{-1}\right)$ and chl a concentration $\left(\mathrm{mg} \mathrm{m}^{-3}\right)$. (b) PCM:BC-CA region, using the combination of depth $(\mathrm{m})$ and chl a concentration $\left(\mathrm{mg} \mathrm{m}^{-3}\right)$ chl a concentration. Suitable habitat for this taxon was very limited and was predicted to occur throughout the Aleutian Islands (Fig. 5a). The conditions in the locations of occurrence of this coral family were not similar to the average conditions in the study area, and Paragorgiidae were moderately intolerant of a relatively wide range of environmental conditions (Table 2). The marginality component indicated that suitable habitat was most strongly associated with below average chl a concentrations. The first specialization component explained $47 \%$ of the specialization for this family and was strongly associated with currents, while the remaining specialization was strongly influenced by temperature (Table 2).

In the PCM:BC-CA region, the highest $\rho$ value for Paragorgiidae was 0.66 for the model that combined depth and chl a concentration. Suitable habitat for this taxon was predicted to occur along the shelf break and on many seamounts (Fig. 5b). The conditions in the locations of occurrence of this coral family were similar to the average conditions in the study area, and Paragorgiidae in this location are moderately tolerant of a relatively wide range of environmental conditions (Table 2). The marginality component indicated that suitable habitat was most strongly associated with above average chl a concentrations. With only 2 environmental factors present in the combination, the specialization factor became null as it must become perpendicular to the marginality factor to maintain uncorrelated axes (Table 2).

For Primnoidae, $\rho$ values ranged from 0.40 to 0.90 in PCM:AK (Fig. 4c), and 0.02 to 0.86 in the PCM:BC-CA region (Fig. 4d). In the PCM:AK, the model that included depth, slope, current and chl a concentration had the highest $\rho$. As for Paragorgiidae, suitable habitat was predicted to be located mainly throughout the Aleutian Islands and on many seamounts (Fig. 6a). This family is moderately intolerant of a wide range of environmental conditions, and the conditions in their habitat were similar to the average conditions in the region. The marginality component indicated that suitable habitat was most strongly associated with belowaverage chl a concentration and above-average depth.

In the PCM:BC-CA region, the highest $\rho$ value for Primnoidae was 0.85 for the model that combined depth, temperature, slope and current. Suitable habitat for this taxon was predicted to occur along the shelf break and on many seamounts (Fig. 6b). As in the PCM-AK area, the conditions in the locations of occurrence of this coral family were similar to the average conditions in the study area. Primnoidae are moder- 


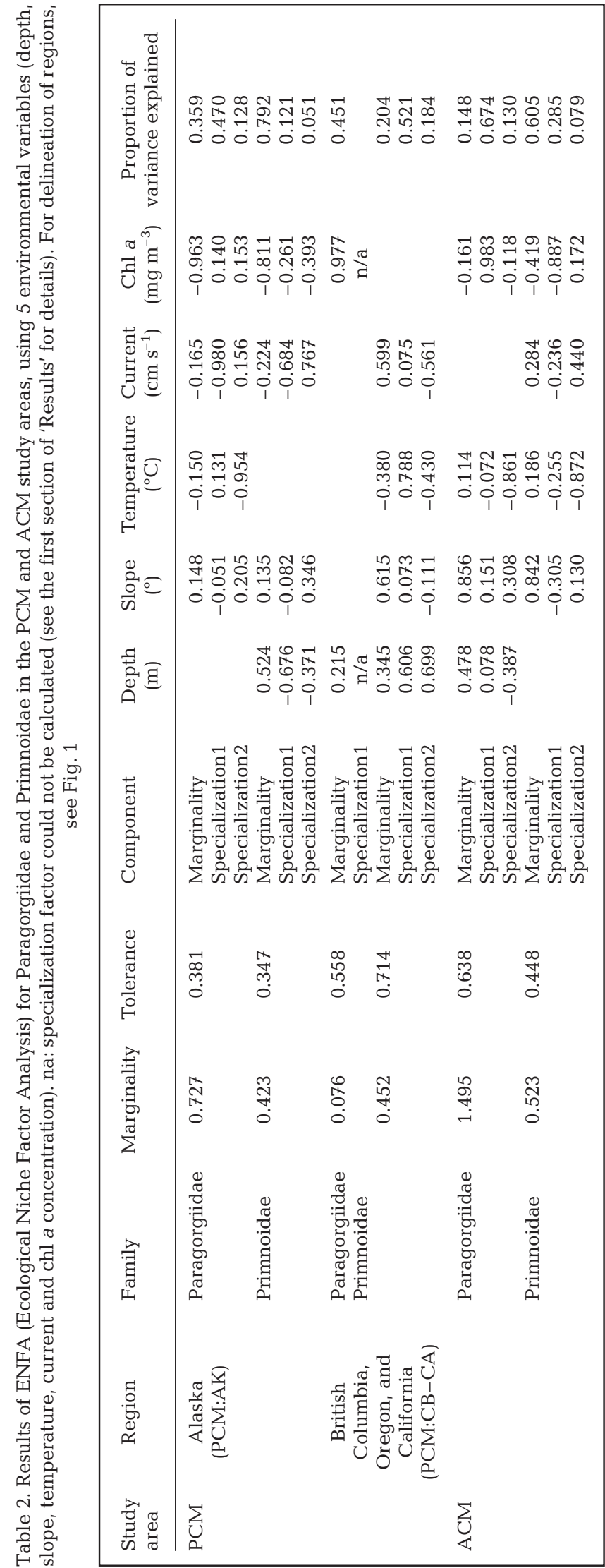

ately tolerant of a relatively wide range of environmental conditions in this region (Table 2). The marginality component indicated that suitable habitat was most strongly associated with above-average slope and currents. The first specialization component explained $52 \%$ of the specialization for this family, and was strongly associated with depth and temperature, while the remaining specialization was strongly influenced by depth and currents (Table 2).

In the ACM study area, Spearman's $\rho$ ranged from 0.10 to 0.71 for Paragorgiidae (Fig. $7 a$ ), and from 0.11 to 0.74 for Primnoidae (Fig. $7 \mathrm{~b}$ ). The highest-ranking combination for Paragorgiidae included depth, temperature, slope and chl a concentration (Fig. 7a). Those areas that were predicted as being suitable were found primarily along the shelf break (Fig. 8). The global marginality value was high, indicating that the conditions in the habitat were not similar to the average conditions in the study area. Tolerance values indicated that Paragorgiidae are moderately tolerant of wide ranging environmental conditions (Table 2). The marginality component indicated that suitable habitat was most strongly associated with above-average slope. This first component explained $15 \%$ of the specialization for this family, with the remaining specialization strongly influenced by chl a concentrations and currents (Table 2). The $F_{\text {aa }}$ curves of this combination were variable, indicating that this combination is not reliable in predicting suitable habitat. This is most likely the result of the small number of Paragorgiidae locations.

For Primnoidae, the model that combined temperature, slope, current and chl a concentration had the highest $\rho$. The Gully, Northeast Channel and Gulf of Maine regions were indicated as being highly suitable habitat (Fig. 9). The conditions in the habitat for Primnoidae were different than the average conditions in the study area. This family is less tolerant to a wide range of environmental conditions than Paragorgiidae. The marginality component indicated a strong, positive influence of slope (Table 2). The first specialization component explained $29 \%$ of the specialization for this family, and was strongly associated with chl a concentration, while the remaining specialization was strongly influenced by temperature (Table 2).

\section{Sensitivity analysis}

In general, variability increased and accuracy decreased in all parameters with the removal of increasingly greater percentages of locations. The difference in average conditions between coral habitats and the study site (indicated by marginality) decreased pronouncedly when the number of locations was 

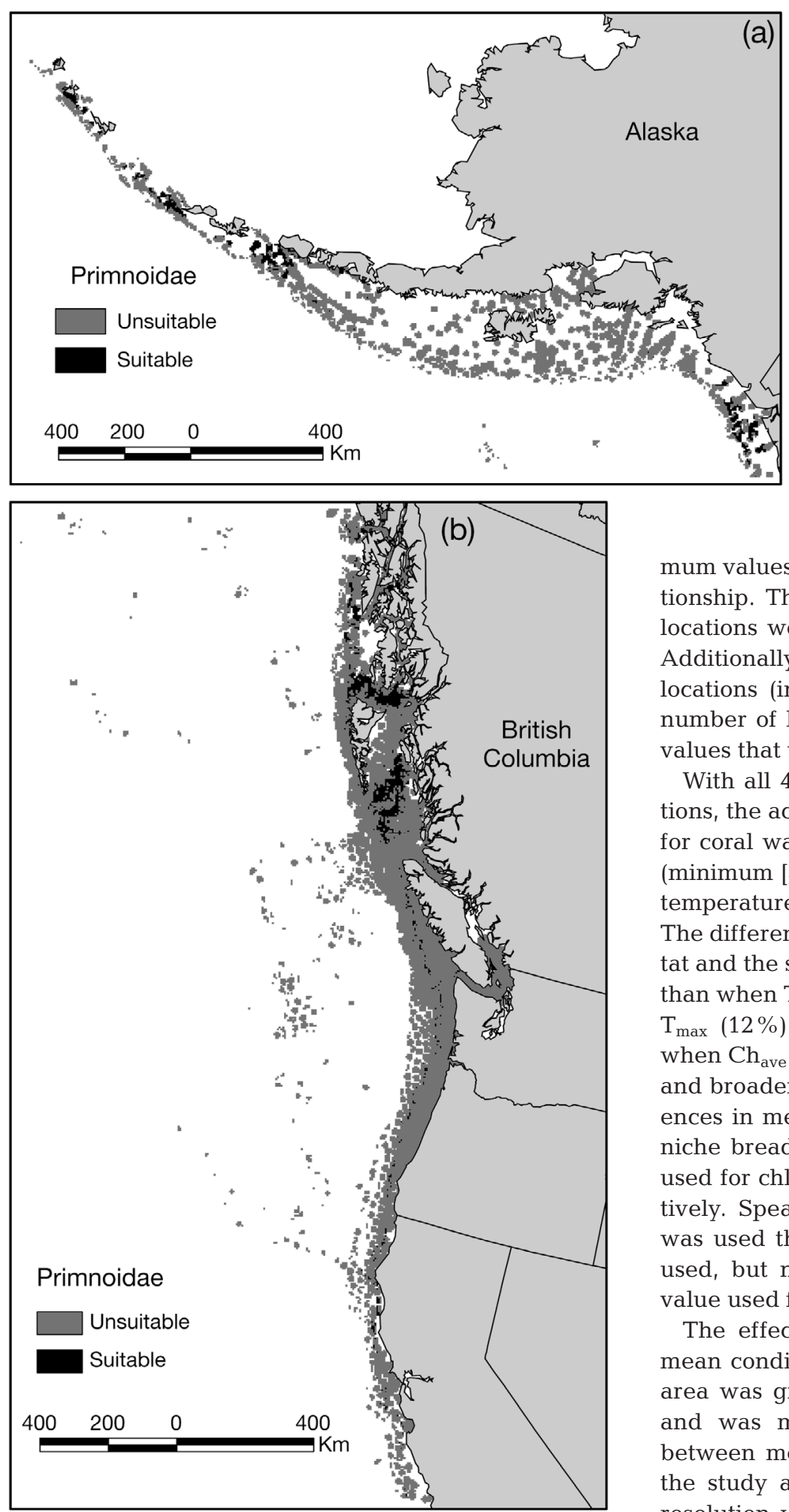

Fig. 6. Habitat suitability map for Primnoidae in the PCM study area generated by ecological niche factor analysis. (a) PCM:AK region, using the combination of depth $(\mathrm{m})$, slope $\left({ }^{\circ}\right)$, current $\left(\mathrm{cm} \mathrm{s}^{-1}\right)$ and chl a concentration $\left(\mathrm{mg} \mathrm{m}^{-3}\right)$. (b) $\mathrm{PCM}$ :BC-CA region, using the combination of depth $(\mathrm{m})$, temperature $\left({ }^{\circ} \mathrm{C}\right)$, slope $\left({ }^{\circ}\right)$ and current $\left(\mathrm{cm} \mathrm{s}^{-1}\right)$ reduced by $10 \%$. The minimum and maximum difference remained relatively unchanged with further reductions, and varied by 9 and $27 \%$, respectively (Table 3). The range between minimum and maximum values was greatest when $90 \%$ of locations were removed. Prediction of niche breadth (indicated by tolerance) was more sensitive to number of locations than that of the relative mean conditions in the coral habitat. A pronounced increase in niche breadth occurred when the number of locations was decreased by $10 \%$. With further decreases in number of locations, the minimum values of niche breadth decreased by $57 \%$, whereas the maximum values varied by $23 \%$ but not in a unimodal relationship. The range in niche breadth widened when locations were reduced by more than $10 \%$ (Table 3 ). Additionally, the range in accuracy in predicting coral locations (indicated by $\rho$ ) increased with decreasing number of locations, and it was mostly the minimum values that were affected.

With all 4 environmental variables in the combinations, the accuracy of the prediction of suitable habitat for coral was minimally affected by the type of value (minimum [min], maximum [max], average [ave]) used for temperature (T) and chl a concentration (Ch) (Table 4). The difference in mean conditions between coral habitat and the study area was smaller when $\mathrm{T}_{\text {ave }}$ was used than when $\mathrm{T}_{\min }(9 \%)$ was used, and greater than when $\mathrm{T}_{\max }(12 \%)$ was used. Niche breadth was narrower when $\mathrm{Ch}_{\text {ave }}$ was used than when $\mathrm{Ch}_{\max }(9 \%)$ was used, and broader than when $\mathrm{Ch}_{\min }(12 \%)$ was used. Differences in mean conditions from the study area and in niche breadth varied by $<5 \%$ with the type of value used for chl a concentration and temperature, respectively. Spearman's $\rho$ values were greater when $\mathrm{T}_{\text {ave }}$ was used than when $\mathrm{T}_{\min }(18 \%)$ or $\mathrm{T}_{\max }(12 \%)$ were used, but no clear pattern emerged for the type of value used for chl a concentration.

The effect of grid resolution on the difference in mean conditions between coral habitat and the study area was greatest between the $1 \times 1$ and $5 \times 5 \mathrm{~km}^{2}$ and was most pronounced for smaller differences between mean conditions in coral habitat relative to the study area $(M<0.200)$ (Table 5$)$. The effect of resolution was much smaller between the $5 \times 5$ and $9 \times 9 \mathrm{~km}^{2}$ resolutions $(<6 \%$ on average across all parameter combinations). Tolerance values (indicative of niche breadth) varied little between resolutions. Comparisons of absolute values of $\rho$ across resolutions are not relevant since $\rho$ is only used to 


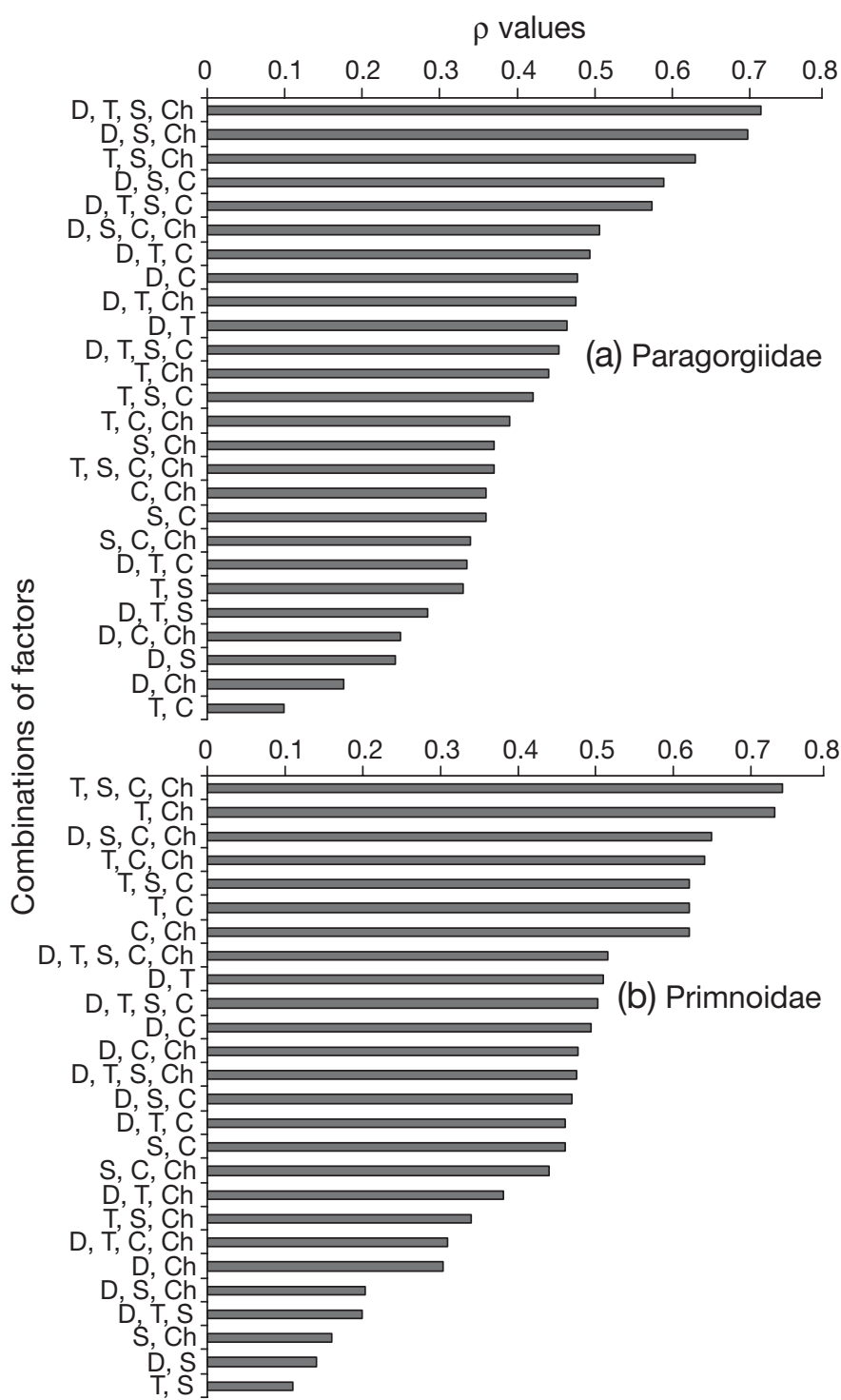

Fig. 7. Spearman's $\rho$ for (a) Paragorgiidae and (b) Primnoidae using all possible combinations of environmental variables to determine suitable habitat for the ACM study area. D: depth, $\mathrm{S}$ : slope, T: temperature, C: current, Ch: chl a concentration

Table 3. Sensitivity analysis of the performance of ENFA to the number of locations included in the analysis. The response variables are marginality, tolerance and $\rho$ values for Primnoidae in the PCM study area in which 0, 10, 30, 50 and $90 \%$ of the locations were removed

\begin{tabular}{|cccccccc|}
\hline \multirow{2}{*}{$\%$ Removed } & \multicolumn{2}{c}{ Marginality } & \multicolumn{2}{c}{ Tolerance } & & \\
& & Min. & Max. & Min. & Max. & Min. & Max. \\
\hline $0(\mathrm{~N}=612)$ & 0.523 & 0.523 & 0.448 & 0.448 & 0.760 & 0.760 \\
$10(\mathrm{~N}=551)$ & 0.254 & 0.284 & 0.711 & 0.781 & 0.650 & 0.900 \\
$30(\mathrm{~N}=428)$ & 0.231 & 0.290 & 0.687 & 0.817 & 0.390 & 0.820 \\
$50(\mathrm{~N}=306)$ & 0.236 & 0.297 & 0.666 & 0.792 & 0.400 & 0.800 \\
$90(\mathrm{~N}=61)$ & 0.239 & 0.391 & 0.307 & 0.633 & 0.240 & 0.910 \\
\hline
\end{tabular}

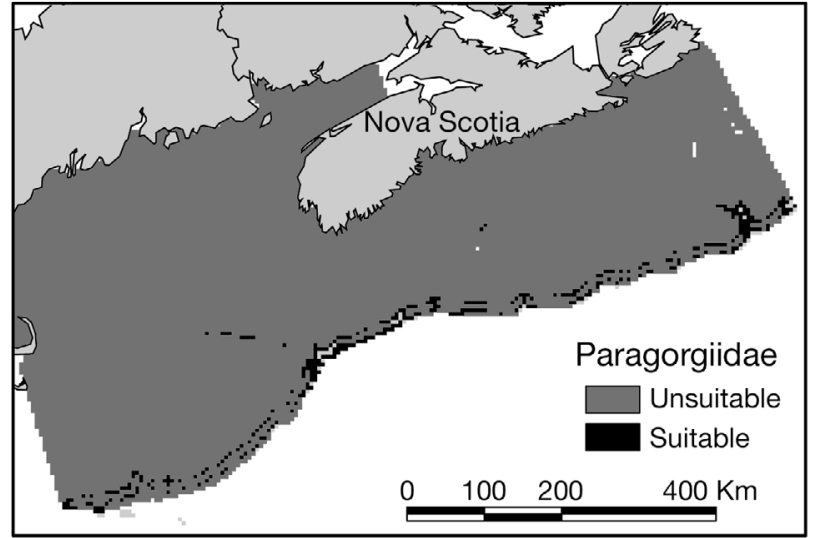

Fig. 8. Habitat suitability map for Paragorgiidae in the ACM study area generated by Ecological Niche Factor Analysis using the combination of depth $(\mathrm{m})$, temperature $\left({ }^{\circ} \mathrm{C}\right)$, slope $\left({ }^{\circ}\right)$ and chl a concentration $\left(\mathrm{mg} \mathrm{m}^{-3}\right)$

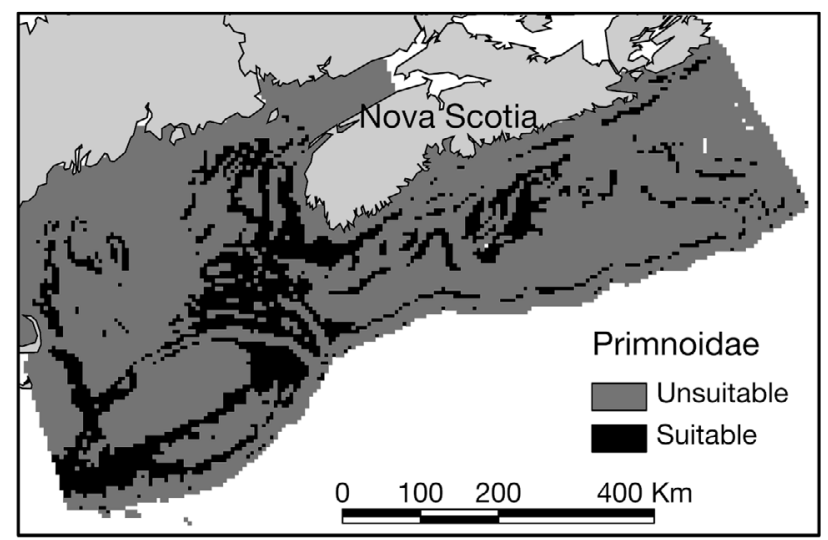

Fig. 9. Habitat suitability map for Primnoidae in the ACM study area generated by Ecological Niche Factor Analysis using the combination of temperature $\left({ }^{\circ} \mathrm{C}\right)$, slope $\left({ }^{\circ}\right)$, current $\left(\mathrm{cm} \mathrm{s}^{-1}\right)$ and $\mathrm{chl}$ a concentration $\left(\mathrm{mg} \mathrm{m}^{-3}\right)$

identify the particular group of combinations of environmental variables that best fit the data.

\section{DISCUSSION}

On both continental margins, coral locations were found to be narrowly distributed within the study areas, and to be present within specific ranges of the environmental factors considered. Although the patterns in habitat characteristics were generally similar, some differences existed between families that related to the ranges of particular environmental factors in their habitat.

In both study areas, corals were predicted to occur in areas of complex topography, mainly along the continental shelf break and on seamounts. In the PCM study area, intense geological activity has formed 
Table 4. Sensitivity analysis of the performance of ENFA in determining habitat suitability to different types of data. The response variables are marginality, tolerance and $\rho$ values for Primnoidae in the ACM study area in which slope (S), current $(\mathrm{C})$, temperature maximum $\left(\mathrm{T}_{\max }\right)$, minimum $\left(\mathrm{T}_{\min }\right)$ or average $\left(\mathrm{T}_{\text {ave }}\right)$, and chlorophyll a concentrations maximum $\left(\mathrm{Ch}_{\max }\right)$, minimum $\left(\mathrm{Ch}_{\min }\right)$ or average $\left(\mathrm{Ch}_{\text {ave }}\right)$ values were utilized

\begin{tabular}{|lccc|}
\hline Combination & Marginality & Tolerance & $\rho$ \\
\hline $\mathrm{S}, \mathrm{C}, \mathrm{T}_{\min }, \mathrm{Ch}_{\min }$ & 0.581 & 0.402 & 0.480 \\
$\mathrm{~S}, \mathrm{C}, \mathrm{T}_{\min }, \mathrm{Ch}_{\text {ave }}$ & 0.577 & 0.446 & 0.520 \\
$\mathrm{~S}, \mathrm{C}, \mathrm{T}_{\min }, \mathrm{Ch}_{\max }$ & 0.573 & 0.521 & 0.680 \\
$\mathrm{~S}, \mathrm{C}, \mathrm{T}_{\text {ave }}, \mathrm{Ch}_{\min }$ & 0.527 & 0.405 & 0.700 \\
$\mathrm{~S}, \mathrm{C}, \mathrm{T}_{\text {ave }} \mathrm{Ch}_{\text {ave }}$ & 0.523 & 0.448 & 0.740 \\
$\mathrm{~S}, \mathrm{C}, \mathrm{T}_{\text {ave }} \mathrm{Ch}_{\max }$ & 0.519 & 0.522 & 0.600 \\
$\mathrm{~S}, \mathrm{C}, \mathrm{T}_{\max }, \mathrm{Ch}_{\min }$ & 0.520 & 0.408 & 0.600 \\
$\mathrm{~S}, \mathrm{C}, \mathrm{T}_{\max } \mathrm{Ch}_{\text {ave }}$ & 0.516 & 0.445 & 0.580 \\
$\mathrm{~S}, \mathrm{C}, \mathrm{T}_{\max }, \mathrm{Ch}_{\max }$ & 0.512 & 0.517 & 0.620 \\
\hline
\end{tabular}

many steeply sloped areas, which are suitable habitat for both families. In the ACM study area, several suitable locations, common to both coral families, included the Northeast Channel, the Gully, and the continental shelf break. As in the PCM study areas, most of these locations are already known to harbour coral assemblages through interviews with fishers and observations from several research cruises (Breeze et al. 1997, Gass 2002). The research conducted in this region has mainly focused on the Northeast Channel and the Gully (e.g. MacIsaac et al. 2001, Gordon \& Fenton 2002), both large submarine canyons along the edge of the continental shelf. Although the ACM study area contains a wide continental shelf, it is riddled with many canyons, gullies and channels.

Except for Paragorgiidae in the PCM:AK region, the conditions in coral habitat in the PCM study area were similar to those in the average habitat in the study

Table 5. Sensitivity analysis of the performance of ENFA in determining habitat suitability using different spatial resolutions of data interpolation. The response variables are marginality (Mar), tolerance (Tol) and $\rho$ values for Primnoidae in the PCM study area in which temperature (T), slope (S), current (C) and chl a concentrations $(\mathrm{Ch})$ values were utilized

\begin{tabular}{|lccccccccc|}
\hline \multirow{2}{*}{ Combination } & \multicolumn{3}{c}{$1 \mathrm{~km}$} & \multicolumn{3}{c}{$5 \mathrm{~km}$} & \multicolumn{3}{c|}{$9 \mathrm{~km}$} \\
& Mar & Tol & $\rho$ & Mar & Tol & $\rho$ & Mar & Tol & $\rho$ \\
\hline C, Ch & 0.092 & 0.911 & 0.21 & 0.075 & 0.903 & 0.16 & 0.109 & 0.971 & 0.38 \\
S, C & 0.083 & 0.884 & 0.52 & 0.145 & 0.876 & 0.16 & 0.145 & 0.876 & 0.42 \\
S, C, Ch & 0.116 & 0.888 & 0.50 & 0.157 & 0.900 & 0.26 & 0.170 & 0.969 & 0.60 \\
S, Ch & 0.108 & 0.963 & 0.46 & 0.152 & 1.004 & 0.48 & 0.151 & 1.059 & 0.50 \\
T, Ch & 0.231 & 0.652 & 0.50 & 0.222 & 0.710 & 0.66 & 0.222 & 0.718 & 0.78 \\
T, C & 0.220 & 0.590 & 0.92 & 0.217 & 0.645 & 0.72 & 0.222 & 0.663 & 0.72 \\
T, S, C, Ch & 0.246 & 0.712 & 0.86 & 0.265 & 0.766 & 0.76 & 0.269 & 0.790 & 0.74 \\
T, S, Ch & 0.242 & 0.708 & 0.72 & 0.261 & 0.771 & 0.76 & 0.257 & 0.786 & 0.62 \\
T, C, Ch & 0.235 & 0.677 & 0.64 & 0.226 & 0.731 & 0.80 & 0.235 & 0.746 & 0.58 \\
T, S, C & 0.232 & 0.669 & 0.80 & 0.257 & 0.720 & 0.86 & 0.258 & 0.735 & 0.80 \\
T, S & 0.228 & 0.635 & 0.74 & 0.254 & 0.691 & 0.90 & 0.246 & 0.693 & 0.68 \\
& & & & & & & & & \\
\hline
\end{tabular}

area, indicated by low global marginality coefficients. In contrast, in the ACM, the optimal habitat was dissimilar to the average habitat in the study area. The ACM study area has a wider continental shelf and more limited steeply sloping areas than the PCM, making the 'average' habitat flatter and softer, and thus less suitable for coral. Similar tolerance values support the observations that Paragorgiidae and Primnoidae often co-exist (Jensen \& Frederiksen 1992).

Although both families had a unique combination of environmental factors which best predicted suitable habitat in each study area, slope and chl a concentration were common environmental factors in all topranking combinations. In the absence of high-resolution substrate data, slope may be considered as a proxy for hard substrate and strong current velocities. Coral locations are predominantly found in areas of low concentration $\left(<3.0 \mathrm{mg} \mathrm{m}^{-3}\right)$ of $\mathrm{chl}$ a as most deep-sea coral locations fall under oligotrophic areas (Bryan \& Metaxas 2006). According to Druffel et al. (1995), the main source of nutrition for many deep-water organisms is surface-derived organic-rich particles. Using isotopic studies of several species of deep-water coral, they have determined that surface-derived particulate organic carbon (POC) is a major source of skeletal carbon (Griffin \& Druffel 1989, Druffel et al. 1995). Deepwater coral would not need to be located beneath areas of high primary productivity to receive adequate levels of nutrition, providing there was adequate lateral advection of POC (Smith \& Kaufmann 1999).

Both currents and temperature were also included in many of the top ranking combinations. Current has been identified as being an important factor in determining suitable coral habitat (White et al. 2005; Bryan \& Metaxas 2006). As deep-water corals are sessile, suspension-feeding organisms that rely on near-bottom currents for nutrient supply, they must exist in habitats with strong currents (Mortensen et al. 2001). Similarly, Mortensen \& Buhl-Mortensen (2004) indicated that gorgonian abundance in the ACM was significantly correlated with average and maximum bottom temperatures.

This is the first study to utilize Biomapper and ENFA to predict suitable habitat in the marine environment. One challenge in this study was the low numbers of occurrence locations, particularly in the ACM study area. Most previous studies using ENFA included hundreds of locations, while in the ACM study area there were $<100$ observations for Primnoidae and Paragorgiidae combined. The number of 
locations in the ACM study area was equal to $12 \%$ of locations in the total PCM study. Based on the sensitivity analysis, we expect that the range in tolerance and $\rho$ values that we estimated in the ACM study area may be wider by $30 \%$ than the real range. This would result in decreased accuracy in the prediction of niche breadth and model fit. However, the estimated marginality values for ACM are assumed to be accurate and our conclusions on the conditions of the species habitat relative to the average conditions in the ACM study area are therefore robust.

A considerable challenge in the use of these (or any) models is the resolution of the available environmental data. Sensitivity analysis indicated that data resolution did not compromise either the estimates of the average conditions in the species habitat relative to those in the study area, or of niche breadth. Interestingly, although the top-ranking combination varied among resolutions, the 6 combinations with the highest $\rho$ and the 4 combinations with the lowest $\rho$ were the same across all 3 resolutions. Thus, it is possible to identify the groups of parameters that are either the most or the least relevant in determining suitable habitat, across a range of resolutions. However, the role of resolution in selecting the top-ranking combination is not known. Consequently, limiting the amount of interpolation of the original data will help ensure the most accurate models are produced.

The generated HS maps are only the first step in determining potential locations of deep-water gorgonian corals. This analysis has generated coarse-resolution maps of HS. Also, it has allowed us to more accurately describe suitable coral habitat by indicating the relative importance of different oceanographic variables. Because of the limited access to the deep sea and the great costs associated with exploration, it is necessary to be able to effectively map target areas. Thus, more research is needed to increase the resolution of the maps, as well as to ground-truth specific areas. As the coarse resolution of the datasets makes it difficult to determine precise information on deepwater coral habitat, the existing information needs to be assessed relative to known biological requirements. For example, it is known that substrate is a major limiting factor for these organisms. Ideally, the locations indicated by using ENFA as being suitable would be validated with a more detailed geological chart if available. The evaluation of the importance of currents may also be affected by resolution, since it is mainly local currents and eddies which directly affect the corals. Presently, detailed empirical measures of currents over large spatial scales, and particularly at depth, are lacking, and estimates are derived using numerical models. Thus, the error associated with these estimates will propagate through to the calcula- tions in other models, such as ours. Currently, additional work is being conducted to further evaluate the validity of this predictive modeling approach by focusing on smaller areas with higher-resolution data, as well as by using different modeling techniques.

The need to protect deep-water coral from human influences has become more obvious as recent observations in both northeast and northwest Atlantic have found evidence of severe trawling damage to deepwater coral reefs (Fossä et al. 2002, Hall-Spencer et al. 2002). Without a predictive tool, these corals may remain unknown and unprotected. By developing a method that would increase the knowledge of coral locations, marine managers and legislators have the ability to more effectively protect specific areas, while still allowing users, such as industries and fisheries, to have access to nearby areas. Our study provides the first test for such a tool.

Acknowledgements. We thank the many data sources, including P. Auster (National Undersea Research Center), H. Breeze (Bedford Institute of Oceanography, Department of Fisheries and Oceans), M. Foreman (Institute of Ocean Science), C. Fuentes-Yaco (Bedford Institute of Oceanography, Department of Fisheries and Oceans), S. Gass (Scottish Association of Marine Studies), C. Hannah (Bedford Institute of Oceanography, Department of Fisheries and Oceans), C. Jenkins (Institute of Arctic and Alpine Research), V. Kostylev (Geological Survery of Canada), L. Morgan and P. Etnoyer (both of the Marine Conservation Biology Institute), D. Spears (Marine Environmental Data Services Branch), L. Watling (University of Maine) and the World Wildlife Fund - Canada. We would also like to thank A. Hirzel and the many people on the Biomapper Listserv. Funding for this project was provided by grants from the Center for Marine Biodiversity, Ocean Management Research Network Sustainability Node and the Natural Science and Engineering Research Council of Canada. We gratefully acknowledge the valuable reviews of this manuscript by L. Levin, A. Genin and an anonymous reviewer.

\section{LITERATURE CITED}

Alidina H, Roff JC (2003) Classifying and mapping physical habitat types (seascapes) in the Gulf of Maine and the Scotian Shelf: seascape version to May 2003. Rep World Wildlife Fund Canada and Conservation Law Foundation, Halifax, Nova Scotia

Boyce MS, Vernier PR, Nielsen SE, Schmieglow FKA (2002) Evaluations resource selection functions. Ecol Model 157: 281-300

Breeze H, Davis DS, Butler M, Kostylev V (1997) Distribution and status of deep-sea corals off Nova Scotia. Marine Issues Committee Spec Publ 1, Ecology Action Centre, Halifax, Nova Scotia

Bryan TL, Metaxas A (2006) Distribution of deep-water corals along the North American continental margins: relationships with environmental factors. Deep Sea Res I 53:1865-1879

Cimberg RL, Gerrodette T, Muzik K (1981) Habitat requirements and expected distribution of Alaska coral. Final Rep 
54. VTN Oregon, prepared for the Office of Marine Pollution Assessment, Alaska Office, US Department of Commerce, NOAA, OCSEAP, p 207-308

De Mol B, Van Rensbergen P, Pillen S, Van Herrewghe K and 6 others (2002) Large deep-water coral banks in the Porcupine Basin, southwest of Ireland. Mar Geol 188:193-231

Druffel ERM, Griffin S, Witter A, Nelson E, Southon J, Kashgarian M, Vogel J (1995) Gerardia: bristlecone pine of the deep-sea? Geochim Cosmochim Acta 59:5031-5036

Elsner P (1999) The Scotian Shelf 'seascape': using GIS for quantitative resource evaluation and management, a case study. Master of Marine Management thesis, Dalhousie University, Halifax

Etnoyer P (2003) B2B 1.1: Information for conservation planning-Baja California to the Bering Sea, CD ROM. Marine Conservation Biology Institute, Redmont, WA

Fielding AH, Bell JF (1997) A review of methods for the assessment of prediction errors in conservation presence/ absence models. Environ Conserv 24:38-49

Fossä JH, Mortensen PB, Furevik DM (2002) The deep-water coral Lophelia pertusa in Norwegian waters: distribution and fishery impacts. Hydrobiologia 471:1-12

Freiwald A (2002) Reef-forming cold-water corals. In: Wefer G, Billett D, Hebbeln D, Jorgensen BB, Schluter M, Van Weering $\mathrm{T}$ (eds) Ocean margin systems. Springer-Verlag, Berlin, p 365-385

Freiwald A, Wilson JB, Henrich R (1999) Grounding Pleistocene iceberg shape recent deep-water coral reefs. Sediment Geol 125:1-8

Gass SE (2002) An assessment of the distribution and status of deep-sea corals in Atlantic Canada by using both scientific and local forms of knowledge. MES thesis, Dalhousie University, Halifax

Gordon DC Jr, Fenton DG (2002) Advances in understanding the Gully ecosystem: a summary of research projects conducted at the Bedford Institute of Oceanography (1999-2001). Can Tech Rep Fish Aquat Sci 2377, Dartmouth

Genin A, Dayton PK, Lonsdale PF, Spiess FN (1986) Corals on seamount peaks provide evidence of current acceleration over deep-sea topography. Nature 322:59-61

Griffin S, Druffel ERM (1989) Sources of carbon to deep-sea corals. Radiocarbon 31:533-543

Guisan A, Zimmermann NE (2002) Predictive habitat distribution models in ecology. Ecol Model 135:147-186

Hall-Spencer J, Allain V, Fossä JH (2002) Trawling damages to Northeast Atlantic ancient coral reefs. Proc R Soc B 269: 507-511 (doi:10.1098/rspb.2002.1910)

Hannah CG, Shore JA, Loder JW (2001) Seasonal circulation on the western and central Scotian Shelf. J Phys Oceanogr 31(3):591-615

Herring P (2002) The biology of the deep ocean. Oxford University Press, Toronto

Hirzel A (2001) When GIS come to life. Linking landscapeand population ecology for large population management modelling: the case of Ibex (Capra ibex) in Switzerland. $\mathrm{PhD}$ thesis, Institute of Ecology, Laboratory for Conservation Biology, University of Lausanne

Editorial responsibility: Lisa Levin (Contributing Editor), La Jolla, California, USA
Hirzel AH, Arlettaz R (2003) Modeling habitat suitability for complex species distributions by environmental-distance geometric mean. Environ Manage 32:614-623

Hirzel AH, Helfer V, Metral F (2001) Assessing habitat-suitability models with a virtual species. Ecol Model 145: 111-121

Hirzel AH, Hausser J, Chessel D, Perrin N (2002) Ecological-niche factor analysis: how to compute habitatsuitability maps without absence data. Ecology 83: $2027-2036$

Jensen A, Frederiksen R (1992) The fauna associated with the bank-forming deep-water coral Lophelia pertusa (Scleractinaria) on the Faroe Shelf. Sarsia 77:53-69

Leier M (2001) World atlas of the oceans. Firefly Books, New York

MacIsaac K, Bourbonnais C, Kenchington E, Gordon D Jr, Gass S (2001) Observations on the occurrence and habitat preference of corals in Atlantic Canada. In: Willison JHM, Hall J, Gass SE, Kenchington ELR, Butler M, Doherty P (eds) Proceedings of the First International Symposium on Deep-Sea Corals, 30 July-3 August 2000. Ecology Action Center and the Nova Scotia Museum, Halifax, p 58-75

Manly BFJ (1986) Multivariate statistical methods: a primer. Chapman \& Hall, New York, p 59-71

Moore D, Bullis H (1960) A deep-water coral reef in the Gulf of Mexico. Bull Mar Sci Gulf Carib 10:125-128

Mortensen PB, Hovland MT, Fossa JH, Furevik DM (2001) Distribution, abundance and size of Lophelia pertusa coral-reefs in mid-Norway in relation to seabed characteristics. J Mar Biol Assoc UK 81:581-597

Mortensen PB, Buhl-Mortensen L (2004) Distribution of deepwater gorgonian corals in relation to benthic habitat features in the Northeast Channel (Atlantic Canada). Mar Biol 144:1223-1238

Reutter BA, Helfer V, Hirzel AH, Vogel P (2003) Modelling habitat-suitability on the base of museum collections: an example with three sympatric Apodemus species from the Alps. J Biogeogr 30:581-590

Sokal RR, Rohlf FJ (1981) Biometry: the principles and practices of statistics in biological research. WH Freeman, New York

Smith KL Jr, Kaufmann RS (1999) Long-term discrepancy between food supply and demand in the deep eastern North Pacific. Science 284:1174-1177

Tendal OS (1992) The North Atlantic distribution of the Octocoral Paragorgia arborea (L. 1758) (Cnidaria, Anthozoa). Sarsia 77:213-217

White M, Mohn C, deStigter H, Mottram G (2005) Deep-water coral development as a function of hydrodynamics and surface productivity around the submarine banks of the Rockall Trough, NE Atlantic. In: Freiwald A, Roberts JM (eds) Cold-water corals and ecosystems. Spring-Verlag, Berlin, p 503-514

Zaniewski AE, Lehmann A, Overton J McC. (2002) Predicting species spatial distributions using presence-only data: a case study of native New Zealand ferns. Ecol Model 157: $261-280$

Submitted: August 22, 2005; Accepted: June 13, 2006

Proofs received from author(s): January 12, 2007 